\title{
ANALISIS KEMAMPUAN BERPIKIR KRITIS SISWA SMA N 5 KOTA JAMBI MELALUI PEMBELAJARAN BERBASIS MASALAH PADA KONSEP PENCEMARAN LINGKUNGAN
}

\author{
Adek Fujika, Evita Anggereini, Retni S. Budiarti \\ Program Studi Biologi, FKIP Universitas Jambi \\ Email: adek.fujika@yahoo.co.id
}

\begin{abstract}
The purpose of this study was to analyze the students' critical thinking skills through problem-based learning on the concept of an environmental pollution in the city of Jambi SMAN 5 academic year 2015/2016. This research is a descriptive study. The study was conducted on 2 January to 25 February 2015. The research subjects were selected using random sampling techniques as many as 40 students from class X MIA 7. Data is collected using observation sheets, sheet questionnaires, and interviews. This study describes the results of observation sheets, the results of the questionnaire and interview sheet. Overall average high school students' critical thinking skills N 5 Jambi through problem-based learning on the concept of environmental pollution is high. The results obtained from the five indicators critical thinking skills which gives a simple explanation was obtained by $77 \%$ of the analytical results of observation, and $83 \%$ of the results of questionnaire analysis. Indicators build basic skills gained as much as $77 \%$ of the analytical results of observation and $81 \%$ of the results of questionnaire analysis, concluded indicator gained as much as $81 \%$ of the analytical results of observation and $82 \%$ of the results of questionnaire analysis. Indicators provide further explanation was obtained by $82 \%$, from the analysis of observation, and $83 \%$ of the results of questionnaire analysis. Indicators set the strategy and tactics gained as much as $81 \%$ of the analytical results of observation and $84 \%$ of the results of questionnaire analysis. Results of interviews with teachers show that the learning process biology students have used critical thinking skills. Conclusions from this research is the critical thinking skills of students during learning activities in this study in the category of high ability.
\end{abstract}

Key words: Analysis capability, critical thinking, problem-based learning

\section{PENDAHULUAN}

Salah satu upaya dalam bidang
pendidikan yang dapat dilakukan untuk
mencetak SDM yang berkualitas yaitu
dengan membiasakan membentuk budaya
berpikir kritis pada siswa dalam proses
pembelajarannya. Berpikir kritis adalah
suatu kegiatan berpikir dengan tujuan
membuat keputusan masuk akal tentang apa

yang diyakini atau dilakukan. Siswa dituntut untuk dapat menganalisis, mensintesis dan menyimpulkan informasi-informasi yang didapatkan dengan kemampuan berpikir kritisnya, sehingga siswa mampu membedakan antara informasi yang baik dan buruk serta dapat mengambil keputusan terhadap informasi yang didapatkannya melalui berpikir kritis. 
Johnson (2007:183) berpikir kritis merupakan sebuah proses yang terarah dan jelas yang digunakan dalam kegiatan mental seperti memecahkan masalah, mengambil keputusan, membujuk, menganalisis asumsi, dan melakukan penelitian ilmiah. Demikian halnya menurut Cogan (1998:39) yang menyatakan ada banyak manfaat serta pentingnya seseorang berpikir kritis nilai berpikir kritis seseorang khususnya bagaimana cara mengenali dan mengevaluasi, yaitu dapat membantu seseorang untuk sampai pada kesimpulan yang benar, meningkatkan pengetahuan, dapat membuat keputusan yang lebih baik, dapat membujuk orang lain, mampu menjelaskan kebenaran kepada orang lain, dan berkontribusi untuk hidup yang lebih baik. Menurut Eggen dan Kauchak, 2012:126) mengembangkan pemikiran kritis yakni menuntut latihan menemukan pola, menyusun penjelasan, membuat hipotesis, melakukan generalisas, dan mendokumentasikan temuan-temuan dengan bukti.

Berpikir kritis merupakan suatu aktivitas mental yang berguna untuk merumuskan jawaban atau mencari solusi dalam memecahkan suatu masalah. Marzano dalam Slavin (2011:37) menyatakan bahwa salah satu tujuan utama bersekolah adalah meningkatkan kemampuan berpikir kritis siswa. Menurut Syamsu dan Nani (2012:91) siswa sebagai remaja merupakan masa transisi yang sangat penting untuk mengembangkan berpikir kritis.

Berdasarkan observasi awal yang dilakukan di SMA Negeri 5 kota Jambi pada tanggal 12 Oktober 2014, guru menyatakan bahwa kemampuan berpikir kritis siswa masih kurang dalam kegiatan pembelajaran, dan perlu diadakannya pengembangan mengenai berpikir kritis siswa, karena menurut guru berpikir kritis merupakan suatu hal yang penting dan harus dimilki oleh setiap siswa, dengan berpikir kritis dapat membantu siswa dalam memahami konsep pembelajaran maupun memecahkan suatu masalah atau soal dengan baik. Namun kemampuan berpikir kritis bukan merupakan suatu kemampuan yang dapat berkembang dengan sendirinya sering dengan perkembangan fisik manusia. Kemampuan ini harus di dilatih melalui pemberian stimulus yang menuntut seseorang untuk berpikir kritis (Desmita, 2009: 156). Untuk menghadapi hal tersebut guru mencoba membuat kelompok belajar atau kelompok diskusi dan menggunakan model-model pembelajaran. Untuk materi pencemaran lingkungan guru menggunakan model pembelajaran berbasis masalah, guru 
berpendapat masalah pencemaran lingkungan merupakan masalah yang berkaitan dengan kehidupan sehari-hari, dan dengan memberikan contoh-contoh permasalahan lingkungan tersebut melalui pembelajaran berbasis masalah, siswa dapat termotivasi dan dapat mengembangkan kemampuan berpikir kritis siswa.

Arends, 2008:43) menyatakan kolaborasi siswa dalam PBM mendorong penyelidikan dan dialog bersama pengembangan keterampilan berpikir serta keterampilan sosial Tujuan utama PBM bukanlah penyampaian sejumlah besar pengetahuan kepada peserta didik, melainkan pada pengembangan kemampuan berpikir kritis dan kemampan pemecahan masalah dan sekaligus mengembangkan kemampuan peserta didik untuk secara aktif membangun pengetahuan sendiri. Menurut Sutirman (2013:42), model pembelajaran berbasis masalah dapat meningkatkan daya kritis siswa dalam menghadapi dan memecahkan suatu masalah. Model ini memiliki ciri yakni penggunaan masalah kehidupan nyata sebagai sesuatu yang harus dipelajari siswa untuk melatih dan meningkatkan keterampilan berfikir kritis dan pemecahan masalah serta mendapatkan pengetahuan konsep-konsep penting, dimana tugas guru harus memfokuskan diri untuk membantu siswa mencapai keterampilan mengarahkan diri. Pembelajaran berbasis masalah penggunaannya di dalam tingkat berfikir yang lebih tinggi, dalam situasi berorientasi pada masalah, termasuk bagaimana belajar. Begitu juga dengan pendapat Helpen dalam Susanto (2012:122) yang menyatakan pembelajaran berbasis masalah dapat membantu peserta didik untuk mengembangkan keterampilan berpikir dan keterampilan mengatasi masalah, mempelajari peran-peran orang dewasa, dan menjadi pelajar yang mandiri.

\section{METODE}

Penelitian ini menggunakan rancangan penelitian deskriptif yang menggunakan metode penelitian deskriptif analisis. Penentuan subjek penelitian dilakukan dengan teknik random sampling dengan subjek penelitian adalah siswa kelas $\mathrm{X}$ IPA 7 yang berjumlah 40 siswa. Sumber data penelitian ini adalah siswa kelas X IPA 7 sebagai data primer dan guru biologi SMA Negeri 5 Kota Jambi sebagai data sekunder. Instrumen penelitian yang digunakan adalah lembar observasi, angket, serta wawancara. Analisis data penelitian ini yaitu sebagai berikut:

\section{Observasi}


Data penelitian hasil observasi diolah dengan menggunakan analisis statistik dengan menggunakan rumus persentase sebagai berikut (Riduwan, 2011:41):

$$
p=\frac{\Sigma F}{\Sigma N} \mathrm{x} 100 \%
$$

\section{Keterangan:}

$\mathrm{p} \quad=$ persentase

$\Sigma \mathrm{F} \quad=$ Skor jawaban responden

$\Sigma \mathrm{N}=$ Skor total

Tabel 3.3 Kriteria Penafsiran Lembar Observasi

\begin{tabular}{|c|c|c|}
\hline No. & $\begin{array}{c}\text { Persentase } \\
(\%)\end{array}$ & $\begin{array}{c}\text { Kategori/Aspek } \\
\text { Kualitas }\end{array}$ \\
\hline 1. & $81-100$ & Sangat Baik \\
\hline 2. & $61-80$ & Baik \\
\hline 3. & $41-60$ & Sedang \\
\hline 4. & $21-40$ & Buruk \\
\hline 5. & $0-20$ & Buruk Sekali \\
\hline
\end{tabular}

\section{Angket}

Jenis angket adalah angket tertutup yang berbentuk checklist berisi 20 pernyataan. Data penelitian diolah dengan menggunakan analisis statistik dengan menggunakan rumus persentase sebagai berikut (Riduwan, 2011:41)

$p=\frac{\Sigma F}{\Sigma N} \times 100 \%$

Keterangan:

$\mathrm{p} \quad=$ persentase

$\Sigma \mathrm{F} \quad=$ Skor jawaban responden

$\Sigma \mathrm{N} \quad=$ Skor total
Tabel 3.5 Kriteria Penafsiran Lembar Angket

\begin{tabular}{|c|c|c|}
\hline No. & $\begin{array}{c}\text { Persentase } \\
(\%)\end{array}$ & $\begin{array}{c}\text { Kategori/Aspek } \\
\text { Kualitas }\end{array}$ \\
\hline 1. & $81-100$ & Sangat Baik \\
\hline 2. & $61-80$ & Baik \\
\hline 3. & $41-60$ & Sedang \\
\hline 4. & $21-40$ & Buruk \\
\hline 5. & $0-20$ & Buruk Sekali \\
\hline
\end{tabular}

\section{Wawancara}

Hasil wawancara selanjutnya akan dianalisis secara deskriptif kualitatif untuk digunakan sebagai bahan acuan pembahasan dalam data hasil penelitian.

\section{HASIL DAN PEMBAHASAN}

Hasil kemampuan berpikir kritis siswa pada setiap indikatornya diperoleh dari beberapa instrumen diantaranya dari lembar observasi, lembar angket dan wawancara guru.

Hasil yang diperoleh dari setiap indikator menunjukkan bahwa kemampuan berpikir kritis siswa melalui pembelajaran berbasis masalah pada konsep pencemaran lingkungan berada pada kategori tinggi. Berikut Persentase observasi kemampuan berpikir kritis siswa pada gambar 4.1 


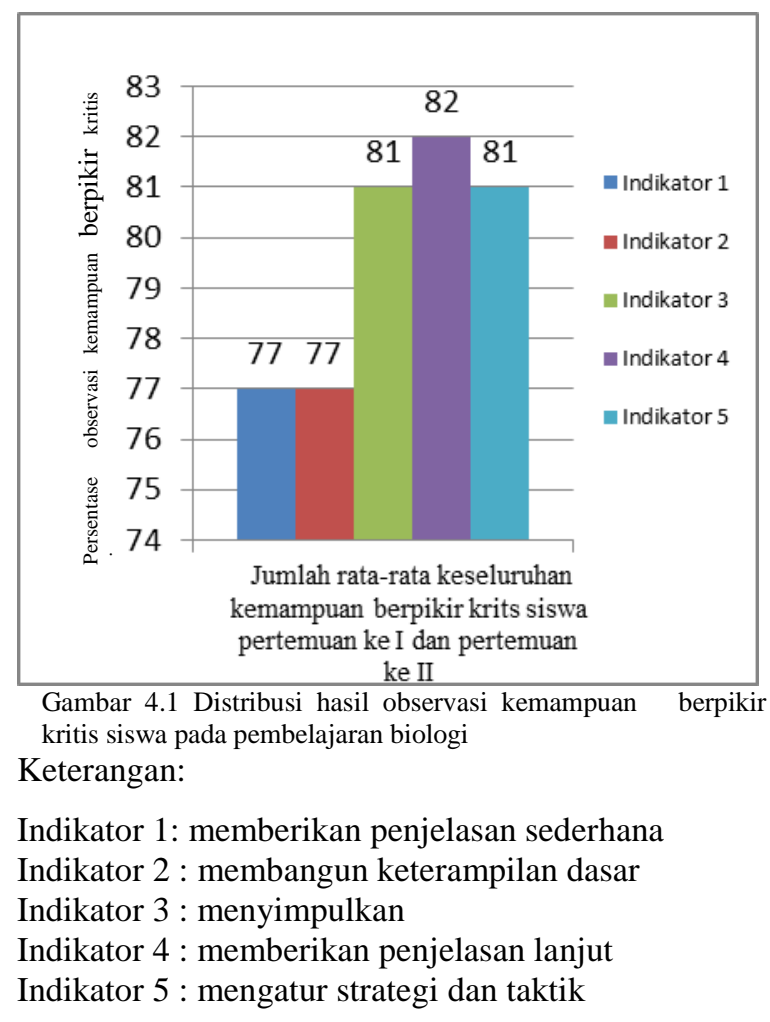

Hasil persentase lembar angket kemampuan berpikir kritis siswa dapat dilihat pada gambar 4.2

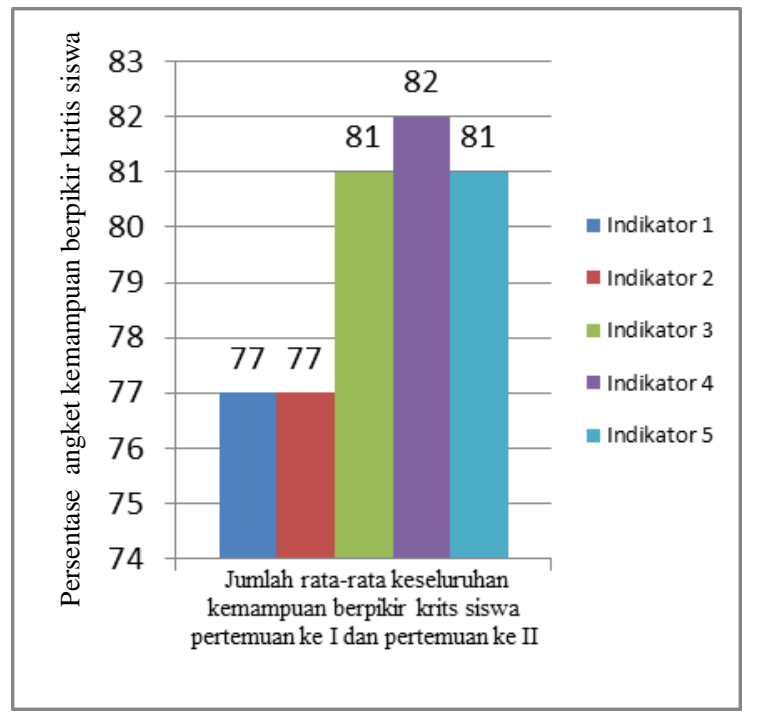

Gambar 4.2 Distribusi hasil angket kemampuan berpikir kritis siswa pada pembelajaran biologi

Keterangan:

Indikator 1: memberikan penjelasan sederhana
Indikator $2:$ membangun keterampilan dasar Indikator 3 : menyimpulkan

Indikator $4:$ memberikan penjelasan lanjut Indikator 5 : mengatur strategi dan taktik

1. Indikator memberikan penjelasan sederhana

Hasil lembar observasi kemampuan berpikir kritis siswa pada indikator memberikan penjelasan sederhana menunjukkan kategori tinggi, hal ini di buktikan dari hasil perolehan lembar observasi dengan persentase $77 \%$ dalam kategori tinggi. Selama kegiatan pembelajaran siswa mampu membuat suatu jawaban sederhana dari suatu permasalahan yang diberikan. Seperti siswa mampu menjelaskan pengertian pencemaran lingkungan, limbah, polusi dan sebagainya. Siswa mampu menyebutkan berbagai jenis dan contoh dari suatu permasalahan yang diberikan. Misalnya siswa mampu menyebutkan berbagai contoh-contoh pencemaran, jenis-jenis limbah, jenis-jenis sampah dan sebagainya.

Sesuai pernyataan Surya (2013:169) bahwa berpikir kritis memungkinkan seseorang untuk menganalisis, menilai, menjelaskan, dan merestrukturisasi pemikirannya. Selaanjutnya siswa mengajukan pertanyaan kepada guru mengenai materi yang belum dipahami dan juga mengajukan pertanyaan pada kelompok 
yang persentasi. Bertanya untuk meminta penjelasan merupakan hal yang perlu dipikirkan karena tanpa berpikir jawaban yang akan disampaikan tidak sesuai dengan jawaban yang akan diharapakan dan siswa sudah terlebih dahulu mengidentifikasi suatu permasalahan tersebut sehingga muncul pertanyaan.

Hasil lembar observasi kemampuan berpikir kritis siswa pada indikator membangun keterampilan dasar menunjukkan kategori tinggi, hal ini di buktikan dari hasil perolehan lembar observasi dengan persentase $77 \%$ dalam kategori tinggi. Sesuai dengan pendapat Surya (2013:167), salah satu ciri pemikir kritis adalah dapat memanfaatkan informasi untuk merumuskan solusi masalah atau mengambil keputusan, dan jika perlu mencari informasi tambahan yang relevan.

2. Membangun keterampilan dasar

Dari lembar observasi kemampuan berpikir kritis siswa pada indikator membangun keterampilan dasar menunjukkan kategori tinggi, hal ini di buktikan dari hasil perolehan lembar observasi dengan persentase $77 \%$ dalam kategori tinggi. Sesuai dengan pendapat Surya (2013:167), salah satu ciri pemikir kritis adalah dapat memanfaatkan informasi untuk merumuskan solusi masalah atau mengambil keputusan, dan jika perlu mencari informasi tambahan yang relevan.

Hasil dari lembar angket kemampuan berpikir kritis siswa pada indikator membangun keterampilan dasar menunjukkan kategori sangat tinggi, hal ini di ditunjukkan dari hasil perolehan lembar angket dengan persentase $81 \%$ dalam kategori sangat tinggi. Surya (2013: 165) bahwa orang yang kritis adalah orang yang cepat mengidentifikasi informasi yang relevan dan memisahkannya dari informasi yang tidak relevan.

3. Menyimpulkan

Dari lembar observasi kemampuan berpikir kritis siswa pada indikator menyimpulkan menunjukkan kategori tinggi, hal ini di buktikan dari hasil perolehan lembar observasi dengan persentase $81 \%$ dengan kategori tinggi. Menurut Susanto (2012: 129-128) salah satu tahapan untuk mengajarkan atau melatih siswa agar mampu berpikir kritis adalah keterampilan menyimpulkan, pembaca dituntut untuk mampu menguraikan dan memahami berbagai aspek secara bertahap agar sampai kepada suatu formula baru yaitu sebuah simpulan.

Hasil dari lembar angket kemampuan berpikir kritis siswa pada indikator menyimpulkan menunjukkan kategori 
sangat tinggi, hal ini di ditunjukkan dari hasil perolehan lembar angket dengan persentase $82 \%$ dalam kategori sangat tinggi. Surya (2013:167), salah satu ciri pemikir kritis adalah dapat memanfaatkan informasi untuk merumuskan solusi masalah atau mengambil keputusan, dan jika perlu mencari informasi tambahan yang relevan.

4. Memberikan penjelasan lanjut

Dari lembar observasi kemampuan berpikir kritis siswa pada indikator menyimpulkan menunjukkan kategori sangat tinggi, hal ini di buktikan dari hasil perolehan lembar observasi dengan persentase $82 \%$ dengan kategori sangat tinggi. Menurut Seifert dan Hoffnung dalam Desmita (2012:154) berpikir kritis yang efektif mengharuskan seseorang untuk memonitor ketika ia mencoba untuk benarbenar memahami suatu ide, menyadari kapan ia memerlukan informasi baru, dan mereka-reka bagaimana ia dapat dengan mudah mengumpulkan dan mempelajari informasi tersebut.

Hasil dari lembar angket kemampuan berpikir kritis siswa pada indikator memberikan penjelasan lanjut menunjukkan kategori sangat tinggi, hal ini di ditunjukkan dari hasil perolehan lembar angket dengan persentase $83 \%$ dalam kategori sangat tinggi. Surya (2013:167), salah satu ciri pemikir kritis adalah dapat memanfaatkan informasi untuk merumuskan solusi masalah atau mengambil keputusan, dan jika perlu mencari informasi tambahan yang relevan.

5. Mengatur strategi dan taktik

Hasil lembar observasi kemampuan berpikir kritis siswa pada indikator mengatur strategi dan taktik menunjukkan kategori tinggi, hal ini di buktikan dari hasil perolehan lembar observasi dengan persentase $81 \%$ dengan kategori tinggi. Surya (2013:167) berpendapat bahwa pemikir kritis memiliki open minded (mendengarkan dengan pikiran terbuka) pada pandangan atau pendapat yang berlawanan dan menerima kritik terhadap keyakinan dan asumsi-asumsi mereka. Disini siswa berdiskusi bersama dalam memecahkan permasalahan saling mengeluarkan pendapat.

Hasil dari lembar angket kemampuan berpikir kritis siswa pada indikator mengatur strategi dan taktik menunjukkan kategori sangat tinggi, hal ini di ditunjukkan dari hasil perolehan lembar angket dengan persentase $84 \%$ dalam kategori sangat tinggi. Sesuai dengan pendapat pendapat Susanto (2012: 129-128) pada keterampilan mengevaluasi atau menilai yang menuntut pembaca agar memberikan penilaian tentang 
nilai yang diukur dengan menggunakan standar tertentu.

Hasil wawancara dengan guru menunjukkan bahwa dalam proses pembelajaran biologi siswa telah menggunakan kemampuan berpikir kritis seperti dalam menjawab soal atau mengajukan pertanyaan dalam pembelajaran biologi pada materi pencemaran lingkungan.

\section{PENUTUP}

Simpulan. Secara keseluruhan rata-rata kemampuan berpikir kritis siswa SMA N 5 Kota Jambi melalui pembelajaran berbasis masalah pada konsep pencemaran lingkungan tergolong tinggi. Yakni diperoleh dari beberapa Indikator keterampilan berpikir kritis yang diteliti dalam kegiatan pembelajaran terdiri dari lima indikator yaitu memberi penjelasan sederhana diperoleh sebesar $77 \%$ dari hasil analisis lembar observasi, dan $83 \%$ dari hasil analisis lembar angket. Indikator membangun keterampilan dasar diperoleh sebanyak $77 \%$ dari hasil analisis lembar observasi dan $81 \%$ dari hasil analisis lembar angket, indikator menyimpulkan diperoleh sebanyak $81 \%$ dari hasil analisis lembar observasi dan $82 \%$ dari hasil analisis lembar angket. Indikator memberikan penjelasan lanjut diperoleh sebanyak $82 \%$, dari hasil analisis lembar observasi, dan $83 \%$ dari hasil analisis angket. Indikator mengatur strategi dan taktik diperoleh sebanyak $83 \%$ dari hasil analisis observasi dan $84 \%$ dari hasil analisis angket.

Saran. Guru diharapkan agar dapat membiasakan siswa untuk melakukan kegiatan berpikir kritis dalam kegaiatan pembelajaran dan dapat mengetahui lebih banyak tentang kemampuan berpikir kritis.

\section{DAFTAR RUJUKAN}

Arends, R I. 2008. Learning To Teach (Belajar Untuk Mengajar), Edisi ke Tujuh. Yogyakarta: Pustaka Pelajar

Cogan, R. 1998. Critical Thinking: Step by Step. United States of America: University Press of America.

Desmita. 2009. Piskologi Perkembangan Peserta Didik (Mengajarkan Konten dan Keterampilan berpikir). Edisi ke enam. Bandung: PT Remaja

Rosdakarya.

Eggen, P dan Kauchak, D. 2012. Strategi dan Model Pembelajaran, Edisi Keenam. Jakarta: PT Indeks Permata Puri Media.

Johnson, B.E. 2007. Contextual Teaching and Learning (Terjemahan). Bandung: MLC.

Riduwan, 2011. Dasar-dasar Statistika. Bandung: Alfabeta.

Slavin,E. R. 2011. Psikologi Pendidikan Teori dan Praktik Edisi Kesembilan Jilid 2. Jakarta: PT. Indeks.

Surya, H. 2013. Belajar Orang Genius. Jakarta: PT. Gramedia 
Susanto, A. 2012. Teori Belajar \& Pembelajaran di Sekolah Dasar. Jakarta: Kencana Prenada Media Group.

Sutirman. 2013. Media \& Model-model pembelajaran Invoatif. Yogyakarta: Graha Ilmu.

Syamsu, Y. dan Nani M. S. 2012. Perkembangan Peserta Didik. Jakarta: Pt. Raja Grafido Persada 
